\title{
Pearls \& Oy-sters: Fatal brain edema is a rare complication of severe CACNA1A-related disorder
} Laurence Gauquelin, MD, FRCPC, Cynthia Hawkins, MD, PhD, FRCPC, Emily W.Y. Tam, MDCM, MAS, FRCPC,
Steven P. Miller, MDCM, MAS, FRCPC, and Grace Yoon, MD, FRCPC

Neurology ${ }^{\circledR}$ 2020;94:631-634. doi:10.1212/WNL.0000000000009223

\author{
Correspondence \\ Dr. Yoon \\ grace.yoon@utoronto.ca
}

\section{Pearls}

- Heterozygous pathogenic variants in CACNA1A are associated with 3 classic phenotypes, with variable expression and significant overlap: familial hemiplegic migraine 1 , spinocerebellar ataxia 6 , and episodic ataxia type 2 .

- In addition to the 3 classic phenotypes, there is a more recently described fourth rare and severe presentation characterized by early-onset permanent cerebellar ataxia, developmental delays, seizures, and episodic attacks resembling hemiplegic migraine.

- The severe subtype of CACNA1A-related disorder can be associated with refractory, fatal brain edema.

\section{Oy-sters}

- CACNA1A-related disorder should be considered in the differential diagnosis of childhood-onset ataxia associated with isolated cerebellar atrophy on brain imaging, even in the absence of episodic clinical manifestations.

- CACNA1A-related disorder can mimic an immune-mediated process and should be considered in cases of acute refractory brain edema of unclear etiology.

- A timely and accurate diagnosis of CACNA1A-related disorder has treatment implications; corticosteroids are beneficial during the acute phase of cerebral edema, and attacks may potentially be prevented by early treatment with acetazolamide.

A 5-year-old girl initially presented in the first months of life with hypotonia and eye movement abnormalities. She had instability of primary gaze and saccadic smooth pursuit, and there was evidence of ocular motor apraxia. She then developed cerebellar ataxia, dysarthria, and generalized dystonia. Posturing was most noticeable in the lower extremities. Ataxia was severe, and the patient never walked independently. She did not have any type of headache, and her family history was noncontributory. Brain MRI revealed isolated cerebellar vermis atrophy (figure).

At age 3 years, the patient had a first episode of decreased level of consciousness in the context of fever. She was diagnosed with focal seizures, with left temporal epileptiform interictal discharges on EEG, and signal changes in the left hippocampus on brain MRI. She was treated with levetiracetam, which was later weaned after 2 years of seizure freedom.

The patient was admitted to the intensive care unit at our hospital at age 5 years with a second episode of altered mental status following a minor fall. She was found to be comatose, with prolonged seizures, exacerbated generalized dystonia, and unexplained fevers. CSF studies were unremarkable. Creatine kinase increased to 4,939 U/L (laboratory reference range 75-230) and then returned to normal within 48 hours. EEG revealed right temporal as well as generalized periodic discharges, superimposed on diffuse background slowing. Levetiracetam was

From the Division of Clinical and Metabolic Genetics (L.G., G.Y.) and Division of Neurology (L.G., E.W.Y.T., S.P.M., G.Y.), Department of Paediatrics, and Division of Pathology, Department of Paediatric Laboratory Medicine (C.H.), The Hospital for Sick Children, University of Toronto, Canada.

Go to Neurology.org/N for full disclosures. Funding information and disclosures deemed relevant by the authors, if any, are provided at the end of the article. 


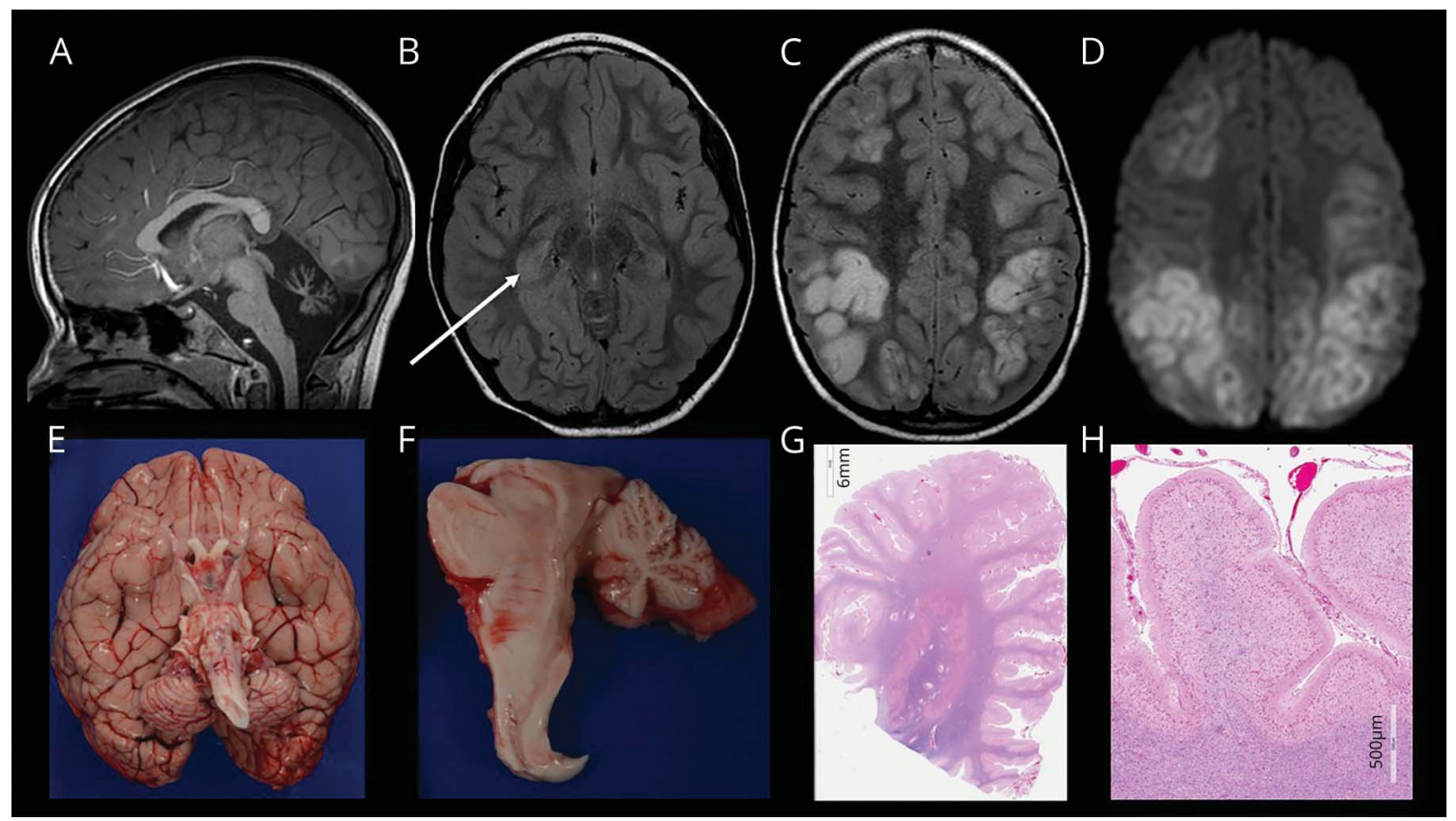

(A-D) Brain MRI obtained at age 5 years, on day 2 (A, B) and day 10 (C, D) of admission. (A) Sagittal T1 image shows atrophy of the cerebellar vermis; (B) axial fluid-attenuated inversion recovery (FLAIR) image shows increased signal and size of the right hippocampus (arrow); (C) axial FLAIR image shows cortical hyperintensities; (D) axial diffusion-weighted imaging sequence shows multiple cortical foci of restricted diffusion with a frontoparietal predominance (corresponding apparent diffusion coefficient map not shown). (E-H) Neuropathologic findings. (E) Gross image of the brain shows the small cerebellum and brainstem; (F) midsagittal section of the brainstem and cerebellum highlights the small vermis and cerebellar hemisphere; (G) whole mount of the cerebellar hemisphere shows atrophy of the folia; $(H)$ higher power image of the cerebellar folia shows complete loss of Purkinje cells and external granular cell layer with gliosis.

restarted, and dystonia was treated with baclofen. Brain imaging was repeated and showed new findings of $\mathrm{T} 2$ and fluidattenuated inversion recovery hypersignal, increased size of the right hippocampus, and multiple foci of cortical diffusion restriction involving both hemispheres, with a frontoparietal predominance (figure, B-D). There was mild interhemispheric pachymeningeal enhancement, but no definitive leptomeningeal enhancement and no parenchymal enhancement. Magnetic resonance spectroscopy was normal.

Despite complete seizure control, the patient remained encephalopathic and continued to require significant ventilatory support. She received pulse steroids (methylprednisolone $30 \mathrm{mg} / \mathrm{kg} /$ dose) from day 5 until day 9 of admission. On day 8, she was found to have a fixed dilated right pupil. Repeat brain imaging showed diffuse edema and bilateral uncal herniation, with low $\mathrm{N}$-acetylaspartate peak and a probable lactate peak on spectroscopy. Intracranial pressure monitoring revealed an initial pressure of $31 \mathrm{~mm}$ $\mathrm{Hg}$ (normal 3-7 mm $\mathrm{Hg}$ in young children). The patient received multiple doses of mannitol in addition to continuous infusion of hypertonic saline over days 8,9 , and 10 of admission. A trial of IV immunoglobulins was started on day 9 given the possibility of an immune-mediated process. On day 10, while on maximal medical treatment for intracranial hypertension, the patient was found to have bilateral fixed dilated pupils with persistent global swelling on repeat brain imaging. A decision was made to withdraw life-sustaining measures, and she died on day 10 of admission.

Chromosomal microarray, metabolic investigations, and a comprehensive brain malformation gene panel had all previously been normal. Skin and muscle biopsy were obtained during the admission at our hospital and were normal. Whole exome sequencing was also pursued and revealed a de novo heterozygous pathogenic variant in the CACNA1A gene (c.5000G>C, p.R1667P) after death.

Postmortem brain biopsy and neuropathologic examination were performed (figure, E-H). The cerebellar vermis and hemispheres appeared atrophic without any other focal lesion within the brainstem. There was complete loss of Purkinje cells. Hemorrhagic lesions involving the cerebral cortex were seen in the right occipital lobe.

\section{Discussion}

Heterozygous pathogenic variants in $C A C N A 1 A$, encoding the a1A subunit of the neuronal P/Q-type voltage-gated calcium channel, are associated with 3 classic phenotypes, with variable expression and significant overlap: familial hemiplegic migraine 1, spinocerebellar ataxia 6 , and episodic ataxia type $2 .{ }^{1}$ More recently, a fourth rare and severe presentation was described, 
characterized by early-onset permanent cerebellar ataxia, developmental delays, seizures, and episodic attacks resembling hemiplegic migraine. ${ }^{2-6}$

It is well-established that episodes of CACNA1A-related hemiplegic migraine can be triggered by minor head trauma and can be associated with altered mental status. ${ }^{1,6}$ In addition, there are a few reports in the literature of severe CACNA1A-related disorder presenting with episodes of prolonged coma, with reversible cerebral edema., ${ }^{4,7}$ These dramatic attacks were previously thought to be specific to the S218L variant but have now been associated with several other CACNA1A pathogenic variants. ${ }^{3}$ Our patient carried a de novo missense variant (c.5000G >C, p.R1667P) that has not previously been reported, but is absent from large population databases.

This is the second report of fatal delayed cerebral edema associated with CACNA1A-related disorder. ${ }^{3}$ This phenotype likely represents the most severe end of the disease spectrum. The mechanisms for brain edema in CACNA1A-related disorder are hypothesized to include a cytotoxic response through dysfunction of the neuronal voltage-gated calcium channels. ${ }^{3,8}$ Aberrant neurotransmitter release has also been described. ${ }^{9}$

During the most recent acute attack, the clinical features of our patient included fever and seizures. Together with the imaging findings of hippocampal signal changes and cerebral edema, the clinical picture was believed to be suspicious for inflammatory/immune-mediated causes, prompting trials of pulse steroids and IV immunoglobulins. The genetic diagnosis was not known at the time. It appears that severe CACNA1A-related disorder can mimic immune-mediated processes or even stroke-like episodes, and should be considered in cases of acute refractory brain edema of unclear etiology.

In addition to intracranial hypertension management (e.g., hypertonic saline, mannitol), treatment with corticosteroids has been reported to be beneficial in a few cases of cerebral edema associated with acute attacks in CACNA1A-related disorder. ${ }^{2,4,6}$ The effect of corticosteroids may be through indirect inhibition of the voltage-dependent calcium channels and by reducing cortical spreading depression. ${ }^{4}$ However, despite pulse methylprednisolone and aggressive intracranial hypertension management, the edema and mass effect progressed rapidly in our patient.

In episodic ataxia type 2, acetazolamide was previously found to be effective in reducing attack frequency. ${ }^{1}$ Familial hemiplegic migraine is also reported to respond to acetazolamide, flunarizine, verapamil, sodium valproate, or lamotrigine. ${ }^{10}$ In the severe phenotypic subtype of CACNA1A-related disorder, results have been inconsistent, with only a few case reports suggesting a benefit of verapamil or acetazolamide. ${ }^{3,7}$
Our patient had initially presented several years before the fatal episode with hypotonia and prominent cerebellar signs, with evidence on brain MRI of isolated cerebellar vermis atrophy. CACNA1A-related disorder is known to be associated with isolated cerebellar atrophy, and should be considered in the differential diagnosis of childhood-onset ataxia with this brain imaging finding, even in the absence of episodic clinical manifestations. An early diagnosis of CACNA1A-related disorder could allow clinicians to consider a trial of preventative medication. Although there is no evidence that such medication would change the outcome, a trial appears reasonable given the severity of acute attacks in patients with the severe phenotypic subtype.

This report illustrates an atypical and severe presentation of a rare genetic disorder. The phenotypic spectrum of CACNA1A-related disorder is broad, and this diagnosis carries important management implications.

\section{Acknowledgment}

L. Gauquelin has received grants from the Canadian Gene Cure Advanced Therapies for Rare Disease (Can-GARD) and from the R.S. McLaughlin and Teva Canada Innovation funds from the Faculty of Medicine, Université Laval. S.P. Miller is supported by the Bloorview Children's Hospital Chair in Paediatric Neuroscience.

\section{Study funding}

No targeted funding reported.

\section{Disclosure}

L. Gauquelin, C. Hawkins, and E.W.Y. Tam report no disclosures. S.P. Miller is supported by the Bloorview Children's Hospital Chair in Paediatric Neuroscience. G. Yoon reports no disclosures. Go to Neurology.org/N for full disclosures.

Appendix Authors

\begin{tabular}{|c|c|c|}
\hline Name & Location & Contribution \\
\hline $\begin{array}{l}\text { Laurence } \\
\text { Gauquelin, MD, } \\
\text { FRCPC }\end{array}$ & $\begin{array}{l}\text { University of } \\
\text { Toronto, } \\
\text { Ontario }\end{array}$ & $\begin{array}{l}\text { Designed and conceptualized the } \\
\text { study, analyzed the data, drafted } \\
\text { the manuscript for intellectual } \\
\text { content }\end{array}$ \\
\hline $\begin{array}{l}\text { Cynthia } \\
\text { Hawkins, MD, } \\
\text { PhD, FRCPC }\end{array}$ & $\begin{array}{l}\text { University of } \\
\text { Toronto, } \\
\text { Ontario }\end{array}$ & $\begin{array}{l}\text { Major role in the acquisition of the } \\
\text { data, interpreted the data, revised } \\
\text { the manuscript for intellectual } \\
\text { content }\end{array}$ \\
\hline $\begin{array}{l}\text { Emily W.Y. Tam, } \\
\text { MDCM, MAS, } \\
\text { FRCPC }\end{array}$ & $\begin{array}{l}\text { University of } \\
\text { Toronto, } \\
\text { Ontario }\end{array}$ & $\begin{array}{l}\text { Interpreted the data, revised the } \\
\text { manuscript for intellectual content }\end{array}$ \\
\hline $\begin{array}{l}\text { Steven P. Miller, } \\
\text { MDCM, MAS, } \\
\text { FRCPC }\end{array}$ & $\begin{array}{l}\text { University of } \\
\text { Toronto, } \\
\text { Ontario }\end{array}$ & $\begin{array}{l}\text { Interpreted the data, revised the } \\
\text { manuscript for intellectual content }\end{array}$ \\
\hline $\begin{array}{l}\text { Grace Yoon, MD, } \\
\text { FRCPC }\end{array}$ & $\begin{array}{l}\text { University of } \\
\text { Toronto, } \\
\text { Ontario }\end{array}$ & $\begin{array}{l}\text { Designed and conceptualized the } \\
\text { study, analyzed the data, revised } \\
\text { the manuscript for intellectual } \\
\text { content, overall study supervision }\end{array}$ \\
\hline
\end{tabular}




\section{References}

1. Terwindt GM, Ophoff RA, Haan J, et al. Variable clinical expression of mutations in the P/Q-type calcium channel gene in familial hemiplegic migraine: Dutch Migraine Genetics Research Group. Neurology 1998;50:1105-1110.

2. Sanchez-Albisua I, Schoning M, Jurkat-Rott K, Lerche H. Possible effect of corticoids on hemiplegic attacks in severe hemiplegic migraine. Pediatr Neurol 2013;49:286-288.

3. Kors EE, Terwindt GM, Vermeulen FL, et al. Delayed cerebral edema and fatal coma after minor head trauma: role of the CACNA1A calcium channel subunit gene and relationship with familial hemiplegic migraine. Ann Neurol 2001;49:753-760.

4. Camia F, Pisciotta L, Morana G, et al. Combined early treatment in hemiplegic attacks related to CACNA1A encephalopathy with brain oedema: blocking the cascade? Cephalalgia 2017;37:1202-1206.

5. Vahedi K, Denier C, Ducros A, et al. CACNA1A gene de novo mutation causing hemiplegic migraine, coma, and cerebellar atrophy. Neurology 2000;55:1040-1042.
6. Curtain RP, Smith RL, Ovcaric M, Griffiths LR. Minor head trauma-induced sporadic hemiplegic migraine coma. Pediatr Neurol 2006;34:329-332.

7. Asghar SJ, Milesi-Halle A, Kaushik C, Glasier C, Sharp GB. Variable manifestations of familial hemiplegic migraine associated with reversible cerebral edema in children. Pediatr Neurol 2012;47:201-204.

8. Chabriat H, Vahedi K, Clark CA, et al. Decreased hemispheric water mobility in hemiplegic migraine related to mutation of CACNA1A gene. Neurology 2000;54: 510-512.

9. Kaja S, Van de Ven RC, Broos LA, et al. Severe and progressive neurotransmitter release aberrations in familial hemiplegic migraine type 1 Cacnala S218L knock-in mice. J Neurophysiol 2010;104:1445-1455.

10. Pelzer N, Stam AH, Haan J, Ferrari MD, Terwindt GM. Familial and sporadic hemiplegic migraine: diagnosis and treatment. Curr Treat Options Neurol 2013;15: $13-27$.

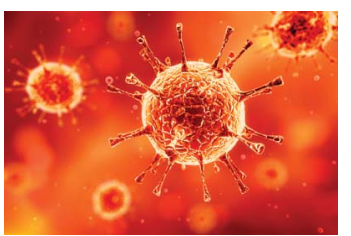

\section{COVID-19 and Neurologic Disease: Call for Papers!}

The editors of Neurology are interested in papers that address the neurological aspects of COVID-19 infection and challenges to the management of patients with chronic neurological conditions who have, or are at risk for, the infection. Relevant papers that pass initial internal review will undergo expedited peer review and online publication. We will consider papers posted in preprint servers.

Submit observational studies and clinical trials as Articles and case series and case reports under the Clinical/Scientific Notes category to https://submit.neurology.org/ today!

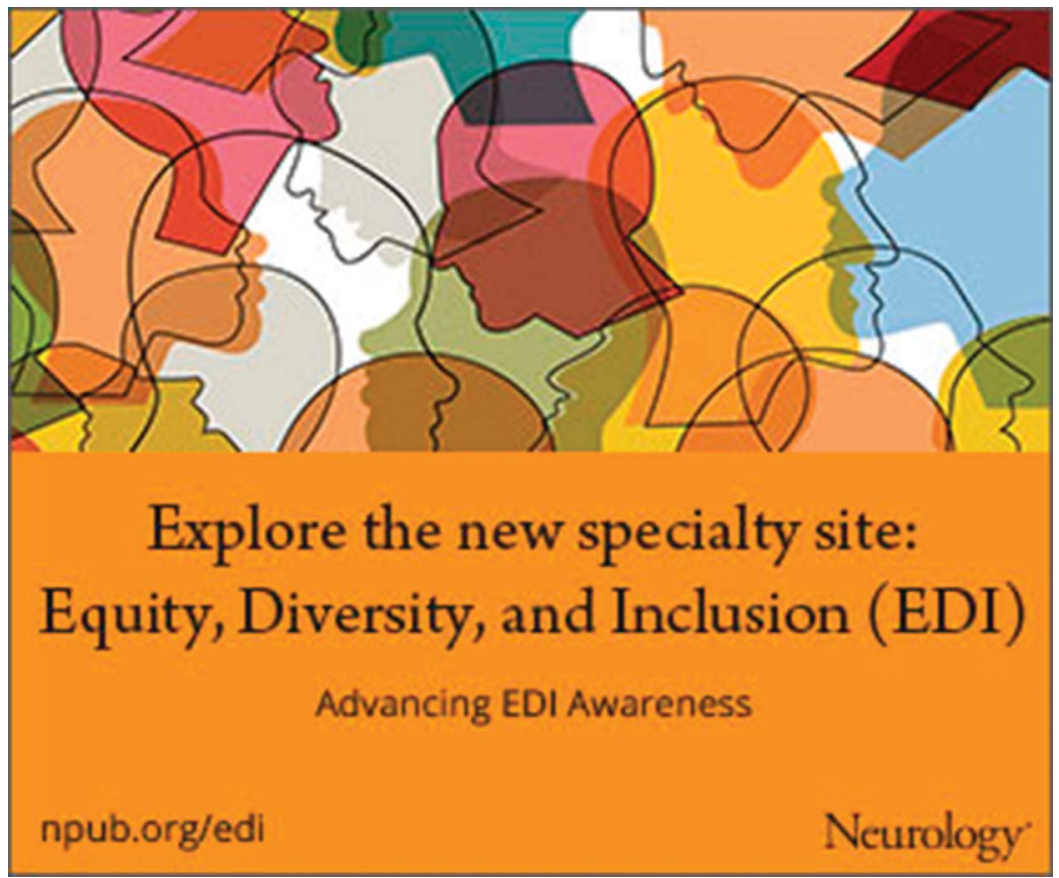




\section{Neurology}

\section{Pearls \& Oy-sters: Fatal brain edema is a rare complication of severe CACNA1A-related disorder}

Laurence Gauquelin, Cynthia Hawkins, Emily W.Y. Tam, et al.

Neurology 2020;94;631-634 Published Online before print March 13, 2020

DOI 10.1212/WNL.0000000000009223

This information is current as of March 13, 2020

\section{Updated Information \& Services}

References

Subspecialty Collections

Permissions \& Licensing

Reprints including high resolution figures, can be found at: http://n.neurology.org/content/94/14/631.full

This article cites 10 articles, 3 of which you can access for free at: http://n.neurology.org/content/94/14/631.full\#ref-list-1

This article, along with others on similar topics, appears in the following collection(s):

\section{Cerebellum}

http://n.neurology.org/cgi/collection/cerebellum

Coma

http://n.neurology.org/cgi/collection/coma

Ion channel gene defects

http://n.neurology.org/cgi/collection/ion_channel_gene_defects

Migraine

http://n.neurology.org/cgi/collection/migraine

Spinocerebellar ataxia

http://n.neurology.org/cgi/collection/spinocerebellar_ataxia

Information about reproducing this article in parts (figures,tables) or in its entirety can be found online at:

http://www.neurology.org/about/about_the_journal\#permissions

Information about ordering reprints can be found online:

http://n.neurology.org/subscribers/advertise

Neurology ${ }^{\circledR}$ is the official journal of the American Academy of Neurology. Published continuously since 1951, it is now a weekly with 48 issues per year. Copyright (O) 2020 American Academy of Neurology. All rights reserved. Print ISSN: 0028-3878. Online ISSN: 1526-632X.

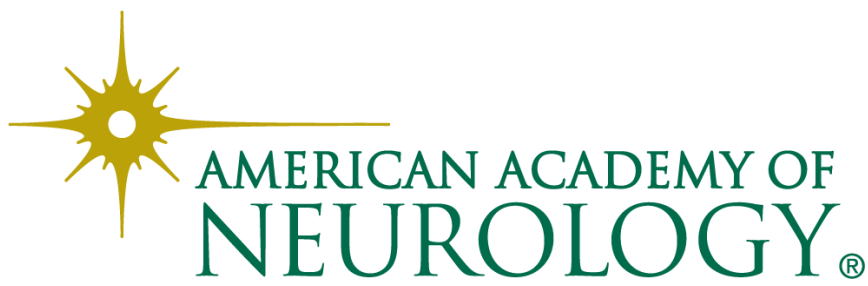

